\title{
Symbolic Boundaries and Moral Demands of Dalit Student Activism
}

\section{Kristina Garalytė}

\section{(2) OpenEdition}

1 Journals

Electronic version

URL: http://journals.openedition.org/samaj/6511

DOI: $10.4000 /$ samaj.6511

ISSN: $1960-6060$

Publisher

Association pour la recherche sur l'Asie du Sud (ARAS)

\section{Electronic reference}

Kristina Garalytè, «Symbolic Boundaries and Moral Demands of Dalit Student Activism », South Asia Multidisciplinary Academic Journal [Online], 22 | 2019, Online since 01 January 2019, connection on 10 December 2020. URL : http://journals.openedition.org/samaj/6511 ; DOI : https://doi.org/10.4000/ samaj. 6511

This text was automatically generated on 10 December 2020.

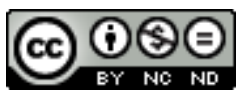

This work is licensed under a Creative Commons Attribution-NonCommercial-NoDerivatives 4.0 International License. 


\title{
Symbolic Boundaries and Moral Demands of Dalit Student Activism
}

\author{
Kristina Garalytè
}

\section{Introduction: Dalit Ethics and Multiple Moralities}

1 This article presents an analysis of a debate between two students of so-called "untouchable origin"1 during which they discussed the moral dictate of "paying back to society." Among Dalit activists, "paying back to the society" is a common explanation for why they engage in Dalit student activism. Such altruism is not solely a Dalit idiosyncrasy, but should rather be seen as reflecting a broader Indian moral concern (Bornstein 2012; Copeman 2011; Jeffrey and Dyson 2014; Srivatsan 2019). ${ }^{3}$ Srivatsan has shown how sevā (social service), "the keystone of ethics of modern India" (2019:24), has reoccurred in different contexts by various forms in the postcolonial Indian history. This research also highlighted how through sevā (social service) hierarchical relations were maintained and altruism used as a means of domination. Contradicting the predominant image of youth in the global South as entangled in "predatory patronclient networks," Jeffrey and Dyson showed how Indian youth in Uttarakhand engaged in "generative politics," by "channeling their energies and time into serving...others," and thus generating new social and political relations (2014: 967-68).

Dalit social responsibility ethics, while resonating with the broader Indian cultural values of altruism, also have their own characteristics and logic rooted in the Dalit movement's history and ideology. The idea of "paying back to society" was introduced by Kanshi Ram, the founder of the Bahujan Samaj Party in Uttar Pradesh. It was based on the vision of the broader Dalit community, which encompasses different exuntouchable groups. Kanshi Ram suggested that having benefited from the quota scheme, upwardly mobile Dalits should reciprocate and work for the betterment of the community. This idea was intended to help overcome the prevalent caste-centrism and competitive division among the SCs while encouraging social responsibility. Naudet 
argued that "paying back to society" has become a central ideological reference of Dalit social mobility $(2008,2018)$.

3 Social responsibility ethos has been a major source for classification and social categorization among Dalits since the beginning of the Dalit movement. In his speeches Ambedkar made a distinction between the "illiterate masses" and the "educated few" whom he denounced for not engaging in social service (Ambedkar, cited in Yengde 2019:155). Kanshi Ram in The Chamcha Age (1982) distinguished the "genuine and real fighters" and "chamchas," stooges of the upper caste Hindus, as different categories (p.90). Recently, Dalit scholar and activist Suraj Yengde critiqued the Dalit middle class in Caste Matters (2019). He identified several Dalit "castegories" according to their different levels of social responsibility. He identifies various Dalit middle class types such as "Token Dalits," "Elite Dalits," "Salaried Hypocrites" and "Self-Obsessed Dalits." A significant and common characteristic of these groups is that they do not overtly embrace Dalit identity or view of caste refraining from contributing to the Dalit community and movement, instead prioritizing personal goals. Yet, Yengde also makes note of another group, the "Radical Dalits" who, proud of their Dalit identity, see the world through the lens of caste and actively engage in political struggle. Hence, we can see that throughout the history of the Dalit movement there has been ongoing concern about the "not-paying-back" members of the community and that movement leaders and community organizers actively reproduced social categorization based on social responsibility attitudes.

4 I will present an ethnographic vignette of two students debating over which means for "paying back to society" are most legitimate. This debate reveals key elements of how categorization figures within micro-contexts. It shows that although "paying back to society" among SC students is a strong structuring moral demand, there are multiple ways in which SC youth perceive, relate to, and enact it. While discussing the conflict, I look at the dynamic relations between the symbolic boundaries revealed by the two students, the way each morally positions himself vis à vis the Dalit community and movement. I also analyze their respective subjectivities in terms of their socioeconomic backgrounds and personal moralities.

5 I will show how the above mentioned differences take the form of symbolic boundaries among the students. Symbolic boundaries are the "conceptual distinctions made by social actors to categorize objects, people, practices, and even time and space" (Lamont, Pendergrass and Pachucki 2015: 853-54). They are assumed to precede and to be "a necessary, but insufficient condition" for the emergence of actual social boundaries (p.169). The latter are governed by concrete rules that distinguish and separate one group from another, while the former are less tangible, essentially conceptual and notional. Contributing to the literature that explores the link between boundaries and morality within social movements (for a literature review see Lamont and Molnár 2015:853-54), I will show how categorization takes place among SC students -"non-activist middle class Dalit" and "Ambedkarite"-and how students draw lines between themselves based on class and, most importantly, relation to the Dalit movement.

6 The question of morality becomes particularly relevant in the context of cultural and societal change. Such contexts produce "moral breakdowns" (Zigon 2007) or "moral torments" (Robbins 2004), as people are forced to respond to particular ethical dilemmas and to match contradicting value systems (Zigon 2007:140-43). Some of the 
SC students on university campuses, as individuals or as a group, have been experiencing intense cultural transformations; illiteracy to literacy, social isolation to social exposure, political socialization through various trajectories. All these changes necessarily affect, but do not determine their moral outlook and likely create a favorable climate for moral dilemmas.

Zigon's approach provides a means for me to examine the moral views of SC students more comprehensively. Instead of viewing morality in terms of totalizing moral discourses and normative uniformity, Zigon urges readers to conceptualize morality in terms of "assemblages," "unique conglomeration(s) of various aspects of diverse and often contradictory discourses, as well as diverse and sometimes incompatible embodied moral dispositions" (Zigon 2014a:18). Departing from the idea of a society composed of separate moral-value spheres (Robbins 2007), ${ }^{4}$ Zigon suggests that "every social context has multi-aspectual moralities that are themselves pluralistic" (2009:263) and that "plurality forms the very 'stuff' of moral experience" (Zigon and Throop 2014:12).

The counter-cultural discourse illustrated by the Dalit movement asserts a distinctiveness and uniformity of ethics and moral code, as if Dalits constitute a moralvalue sphere that is different and, in a way, autonomous from the dominant Hindu cultural morality (Garalyte 2015). Existing research on the Dalit middle class and social mobility suggests that these views are internalized to a significant extent, though not absolutely, among the SC members who identify with the Dalit political project. Naudet has argued that Dalitization-the internalization of Dalit counter-culture narratives and resistance to caste domination-has become the cultural repertoire upwardly mobile Dalits most often draw upon as it allows them to "succeed without betraying" (2018). Srinivas agrees that the Dalit middle class fosters a separate identity, a "product of protest ideology" referring back to B. R. Ambedkar (2016:220). While acknowledging the influence of Ambedkarite ideology in forming students' moral views, I distinguish a plurality of moralities within the SC student community and demonstrate how students, "consciously and creatively find a way to be moral" (Zigon 2009:263). Devan's case in particular deviates from the accepted unilineal identity development trajectory of Dalitization (Charsley 1998; Ilaiah 2009; Naudet 2018, Yengde 2019) revealing the moral dilemmas that may surface during Dalitization. In addition, through this case study, there is opportunity for a re-evaluation of the uniformity of the social experience of untouchability (Guru and Sarukkai 2013) as a key factor in determining Dalitness.

Contributing to the understanding of ethical and moral life in South Asia (Blom and Jaoul 2008; Pandian and Ali 2010), this case study shows that students envision various moral ways to climb the social ladder, and how they deal with the moral dilemmas arising from social mobility. Summarizing existing sociological research on social mobility, Naudet states that "[ $t$ ]he memory of the group of origin is always present and causes the upwardly mobile person to be torn between his attachment to his group of origin and his desire to recognize the social legitimacy of his new group" (2008:416). However, he also argues that "this question of the tension between the group of origin and the new group does not play the structuring role in the Indian context, that it does in Western sociological literature" (2008:416). This case study, in contrast, brings out tensions that arise at the intersection between Dalit movement's ethics and multiple individual moralities. ${ }^{5}$ argue that in the case of SC students, moralities should not be 
reduced to social categories (e.g. Dalits) or ideological claims (e.g. "paying back to society") but instead should be considered taking into account their complexity and their actual everyday manifestations in line with the "ordinary ethics" (Lambek 2010; Das 2012) and phenomenological approach (Zigon 2009, 2014a, 2014b; Zigon and Throop 2014) rather than through explicit ethical discourses, codes and rules.

\section{Dalit Activism on Indian University Campuses}

Scheduled Castes have been guaranteed reserved seats in governmental education institutions by the Constitution of India since 1950; however, their visibility within universities has grown gradually. While the emergence of other student political groups goes back to the time of the Indian independence movement (Altbach 1968; Shah 2004; Wilkinson 2020), Dalits as political actors with distinct political identity, started mobilizing on campuses in the 1990s, when Indian society and politics underwent significant systemic changes. ${ }^{6}$ In the context of these broader shifts, various Dalit and other lower-caste student organizations came into being, mobilizing on caste identity and for improving the political climate of some Indian university campuses. These new caste identity-based organizations began and continue to defend the constitutional rights of ex-untouchables with regard to education, lobby against caste discrimination, and fight for public representation of this recently politically recognized and defined group.

11 Early scholarly accounts of the Indian student movement and campus politics barely mention Dalit and caste issues (for a literature review see Shah 2004), and Dalit political activism came to popular and scholarly attention only recently. SC students on Indian university campuses have been mainly analyzed in terms of their experience with caste discrimination and inequality in the field of higher education (Desai and Kulkarni 2008; Pathania and Tierney 2018; Ovichegan 2014, 2015; Pandey and Pandey 2018; Sen and Gundemeda 2015). Meanwhile, Jeffrey $(2008,2010)$ analyzed Dalit student mobilization in Uttar Pradesh where Dalits asserted their moral superiority with regard to the dominant Jat student groups, and attempted to gain symbolic control of the university space.

What received more academic attention is the Beef and Asura counter-culture politics ${ }^{7}$ through which Dalit students challenged dominant Hindu practices and beliefs and expressed their cultural distinctiveness and autonomy (Gundimeda 2009; Garalyte 2015; Pathania 2016). Dalits and caste issues also appear episodically in other ethnographic accounts that look at overall campus political culture (Kumar 2012; Martelli and Parkar 2018), while Pathania looked at Dalit student participation in the Telangana movement on the Osmania University campus (2018). All these works largely explore the ways in which Dalit students position themselves with regard to other student groups and the broader social caste structure; less attention has been paid to SC intragroup relations and dynamics and the ways SC students perceive and relate to the Dalit political activism. Ovichegan $(2014,2015)$ showed the distinction between economically affluent, "creamy-layer" Dalits, and economically weaker SC students (2014:368). However, his analysis does not take into consideration the role of the Dalit movement and campus politics in determining intra-group ideological differentiation. Drawing on the notion of symbolic boundaries (Lamont and Fournier 1992; Lamont and Molnár 2002; Lamont, Pendergrass and Pachucki 2015), this article explores the 
emerging differentiation within the SC student community at the intersection between caste, campus politics and social movement experience, resulting in a more comprehensive understanding of Dalit students as a socially and politically heterogeneous group.

\section{Research Site and Methodology}

13 I will discuss SC students at Jawaharlal Nehru University, the stronghold of Leftist politics (Batabyal 2015) where I conducted ethnographic research from March to June, 2013. ${ }^{8}$ My field research data comes from semi-structured interviews and conversations with Dalit student activists, Dalit professors, students from other political groups, and politically disengaged students held in popular gathering places. Interviews focused on students' life stories and campus experiences. A significant part of the research data comes from participant observation of everyday campus life and through conversations gathered as I was "moving with the participants through their space and time" (Burawoy 1998:14).

14 I follow Burawoy's reflexive science approach that "takes context and situation as its points of departure" and looks at everyday social interaction (1998:30). The main narrative of the article revolves around an argument between two SC students while they were in a local hangout discussing "giving back to society." I was present at this discussion and as a result of my ongoing participation in their everyday activities, I did not appear to have any effect on the way they expressed their respective moral and political stances regarding what counts as "paying back to society." As I understood it, the conflict destabilized and problematized the ideological reproduction of the normative discourse of the Dalit movement and allowed me to discern the plurality of experiences and moral views among SC students. Such a natural, unforeseen situation, rather than a strictly scripted research plan, allowed me to better grasp what Burawoy has called "situational knowledge" and tacit social relations (1998:15).

In order to understand in what broader socio-political context the discussed conflict appeared, it is worthwhile to present an overview of the social field of Dalit student activism on the JNU campus. In 2013, the concerns of Dalit students were advocated by a number of student groups such as UDSF (United Dalit Students' Forum), AIBSF (All India Backward Students' Forum), BSF (Bahujan Students' Front), Mulnivasi Sangh and The New Materialists. Each of these groups claimed to represent subaltern lower caste communities in a different way. UDSF mainly addressed Dalit issues from the Ambedkarite perspective and claimed default membership, meaning that all SC and ST students on campus were seen as natural members of UDSF. AIBSF and BSF searched for broader alliances with the OBCs (Other Backward Classes) working from the Bahujan (majority) ${ }^{9}$ angle. The New Materialists merged Ambedkarite and Marxist perspectives, while Mulnivasi Sangh experimented with focusing on autochthon and race. The existence of these different groups shows that the subaltern student activism on the JNU campus was fragmented and faced ideological and practical difficulties in forming a common political platform. "Whenever SCs, STs and OBCs start coming together, something comes up in the market that creates divisions," Prem, one of the protagonists of this article, aptly sums up the perennial problem of subaltern politics in India. ${ }^{10}$ 
16 Despite their differences, the groups above engaged in similar and quite often collaborative activities. They organized intellectual and awareness programs during which students and scholars debated Ambedkarite ideology, caste issues and DalitBahujan culture. Some of the groups, such as BSF and AIBSF, contested JNUSU elections several times, although without major victories. ${ }^{11}$ Dalit and pro-Dalit student activism with its caste critique and claim to represent subaltern groups, though at the margins of electoral campus politics, had a growing ideological resonance with the Leftdominated campus. Dalit student activist groups resembled a loose network with flexible boundaries, unlike the strict organizational structure displayed by the more established student organizations. What mostly characterized Dalit student activism on the JNU campus was the intersectionality between diverse groups and ideological discourses: leftists, autochthon, feminist, regional etc. Martelli's account (2020) illustrates that, in general, "ideological cross-fertilization" can be seen as a major characteristic of JNU student politics.

17 In early efforts in the 1990s, during the anti-Mandal protests, Dalits at the JNU and other university campuses mainly mobilized to safeguard the reservation system and to engage in identity politics. Twenty-five years later, victimization sentiments gave way to the more radical claims of Dalit counter-culture and Dalit moral superiority. ${ }^{12}$ Dalit students criticized other student groups for perpetuating caste order and caste mentality and represented themselves as culturally autonomous and morally superior citizens and political actors (Garalytè 2016).

The university campus environment, which shelters social, cultural and political diversity, is an extremely rich site to research how people experiment with their social and political identities while simultaneously negotiating their moral views. We will see that at JNU, as I believe is common to other politically vibrant South Asian campuses, political mobilization goes hand in hand with moral socialization.

\section{Differing Experiences and Moralities}

My arrival in New Delhi (March 2013) coincided with the conference "Dalit Art and Visual Imagery" held at JNU on the occasion of the publication of G. M. Tartakov's eponymous edited volume. At the entrance to the auditorium where the Dalit conference was held, there was an exhibition of the varied Dalit artwork that was discussed during the conference, ranging from works by the renowned painter, Savi Savarkar, to those by lesser known Dalit folk artists. At the end of the last conference day, while I was standing and looking at a painting depicting caste discrimination scenes from a Bihari village, a student in his early twenties approached me and asked if I understood what was depicted in them. He asked me about the painting, he said, because he was a Dalit from Bihar and could offer me an explanation of what it depicted.

Devan ${ }^{13}$ became one of my closest informants in JNU. I met with him regularlydrinking tea in $d h \bar{a} b \bar{a}$ (food stalls), roaming around and attending events. Devan once invited me for a poetry reading called "Caste Away" in the Kunzum Travel Cafe in Hauz Khas village, a gentrifying neighborhood and popular hang-out place among middle class Delhiites. During the event Devan read his poem, winning two awards for the best Hindi poem and the best line. On another occasion, Devan invited me to a theatre play in which he was performing. We went to the play together with his new upper-caste 
friend and her parents. Compared to other Dalits who usually socialized with fellow Dalits or other self-described subaltern students, Devan had a set of social contacts beyond his caste and class boundaries and also beyond one type of political group.

Devan's relation to Dalit student activism was ambivalent. He was interested in Dalit issues and Dalit politics, but did not participate in Dalit student activism and was reluctant to make public comments during the Dalit events held on campus. Devan's interest in the Dalit topic became more evident as he gradually engaged in my field research, suggesting what people I should meet and participating in the informal interviews that were often more like spirited table discussions. Devan introduced me to several student activists who were not from SC background, but were engaged or supportive towards the Dalit student movement, as well as student leaders from other student organizations.

I got to know more about his background from his friends than from Devan himself. His reluctance to tell his life story stands in a sharp contrast to the Dalit activists' willingness to share theirs. Interestingly, Devan did not describe his life as "suffering or struggle," although he did narrate one incident that he faced at school related to drinking water, ${ }^{14}$ a common experience among Dalit students. Devan comes from an educated, intellectual Ambedkarite family. His father was the first in his generation to be educated, and despite difficulties managed to rise up to the position of school principal in Bihar. The only time Devan spoke about his father, he said that his father had a good friend who was a Brahmin and an active Hindutva supporter. Apparently, their common interest in poetry strengthened their bond. Devan recalled that the Brahmin friend had helped Devan's father a great deal. For example, he once filled out an application for a higher teaching position on behalf of Devan's father, which eventually led to his promotion. "They were eating, sleeping together, using the same utensils. This fact attracts me a lot," Devan recalled. I got the impression that Devan, motivated by his father's experience, was especially interested in understanding uppercaste people's involvement in the Dalit movement and their intentions: whether their support was genuine or merely related to practical calculations. Altogether, Devan was an ambivalent figure, talking and acting differently from most of the Dalits whom I met and who were active in the Dalit movement.

On May $23^{\text {rd }}, 2013$ Devan came with me to meet Prem, ${ }^{15}$ a Dalit activist belonging to one subaltern student organization on the JNU campus. This was their first direct encounter, though both agreed that they were aware of each other on campus. This was also the first time when Prem and I engaged in a longer conversation covering diverse political topics such as different Dalit student organizations on the JNU campus, existing political and economic divisions among Dalits and the future of the Dalit movement. In the interview, he criticized the use of the label "Dalit" for its degrading connotation and also for its part in obstructing the building of broader alliances with other oppressed communities. He felt much more comfortable defining himself as Mülnivāsi (Originals of land), an identity term which asserted that SC, ST and OBC communities were the original inhabitants of the Indian subcontinent and share a racial affinity and potential to revolutionize Indian society. Ideologically, Prem defined himself as being Phule-Ambedkarite. ${ }^{16}$ From time to time, Devan interjected short affirmative comments and questions into the interview such as: How Ambedkar's ideas relate to the idea of a revolution; how academicians perceive the Mulnivasi term; why different Dalit groups do not work together under the same banner; whether unity 
among Dalits should be based on Ambedkar's ideology or rather merely on identity? The general mood of the interview was cheerful and there were no signs of tension as Prem expressed his ideas and knowledge about Dalit politics.

After approximately one hour of our conversation, Raju, a Dalit student activist, and friend of Prem, came and joined us. I had met Raju several times on other occasions before this meeting and we had already established a friendly relationship. Raju came from Haryana and his life story displayed a dramatic pathway of upward social mobility. Raju was from an uneducated and economically backward SC family but he managed to get admission in the prestigious and elite education institution in the capital. He adopted his maternal grandfather's surname because his real one was typical among ex-untouchables and immediately revealed his caste identity, a big obstacle in his professional field. Raju explained to me that his inspiration for political activism came from his mother, who once rebelled against the insults of upper caste villagers by refusing to continue working until they apologized. Raju repeatedly noted that there was an urgent need to create Dalit media and to educate Dalits as journalists, because according to him, all Indian media, especially English media, was dominated by upper-castes and their discourse. He was equally critical of Indian higher education and shared the common view of Dalit activists that Indian universities were Brāhmin agräharam ${ }^{17}$ and thus replicating the social exclusion existing in villages. During the time of my fieldwork, Raju was actively involved in organizing FYUP protests. ${ }^{18} \mathrm{He}$, in the company of other activists, took me along on visits to New Delhi Dalit politicians as the students searched for political support.

For some ten minutes, Raju simply observed the discussion between Prem, Devan and I, as we talked informally although with a digital tape recorder on "record." Eventually, I asked my final question, igniting a passionate discussion that eventually turned into an agitated dispute; the question was about their future plans. Initially all of them agreed that they would likely pursue an academic career; then the conversation took a very different turn. Addressing the activists as elders in the respectful pronoun "Sir," Devan declared:

$\bar{A} p$ bol sakte hain ki main...main...matlab is māmle men thoda avasarvādī hūn... Opportunist mere liye negative term nahin hai...Merā mannā hai ki if you are fighting against Brahmanism you have to use same tool to fight against Brahmanism [as] they are using. (You can say that I...I...mean...in this case I am a bit opportunist...Opportunism for me is not a negative term...I think that if you are fighting against Brahmanism you have to use the same tool to fight against Brahmanism that they are using)

As an artist, Devan expressed his individualism and apolitical stance:

Main kisī group kā part nahīn bannā chāhtā hūn, nahīn ban saktā hūn, kisī movement kā part nahīn bannā chāhtā hūn. Thīk hai? Sīdhī bāt hai?[...]Mujhe ambeḍkarvādiyon pe viśvās nahin hai. (I don't want to join any group. I cannot join any group. I don't want to become a part of any movement. OK? Straight point? ...I don't believe in Ambedkarites). ${ }^{19}$

I can only guess whether Devan's open demonstration of his opportunistic views was intended to provoke the activists, to be intimately honest, or to show off. Unsurprisingly, activists Prem and Raju, became irritated by his comments-his mentioning of Brahmanism and its methods, his admission of being both opportunistic and politically disengaged. This is exactly what Ambedkarism inveighs as morally 
corrupt-Dalits who succeed and do not concern themselves with their group and their structural, symbolic and material marginalization in society. Prem and Raju were radically opposed to the views expressed by Devan. Instead they inveighed the collective ethos of Ambedkarism, entailing a moral responsibility to the Dalit community. For the activists, political engagement was a moral act, a way to "pay back to society." For Devan, politics was associated with dirty business. ${ }^{20}$ Devan tried to explain that he is working in his own cultural ways (cultural admī hūm), researching Dalit literature, cinema and art. However, Raju did not seem to take it seriously and maintained his negative perception of Devan. Raju and Devan now led the discussion, with me remaining as a passive recording observer. Raju positioned himself as the interviewer pushing Devan into a corner with his questions: Aur āp change lānā chāhte hain. Without movement kā part bannā, very good... (How can you change society if you are not participating in the movement? Very good...) followed by demonstrative ironic clapping.

To illustrate what made the activists so irritated by Devan, I provide a short excerpt from their conversation:

Devan: Mujhko kuch fāydā nahīn hai. Phir bhī main kuch denā chāhtā hūn, thîk hai, na? Isliye politics mere liye nahin hai. (I don't get any benefit, but I want to give something, OK? That's why politics are not for me.)

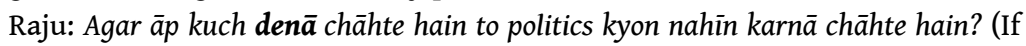
you want to give something, why are politics not for you?)

Devan: main dūngāa, na. Main apne tarīqe se dūng. (I will give, I will give in my way.)

Raju: $\bar{a} p$ kyā denge, āp kis tariqe se denge? (What will you give? In what way will you give?)

Devan: Main kisī tariqe se dūngā. Maine batāyā ki mujhe money chāhiye. Uske binā I cannot do anything uske binā. (I will give in some way. I have said that I need money. Without it I cannot do anything.)

Raju: To money kahān se milegā? (So how you will get money?)

Devan: Main apnā rāstā talāś kar lungā. Agar ye system brahmanical hai, to main isī brahmanical system se money raise karūngā...āpko academics me jānā hai. Agar main academics men jātā hūn, main paisā raise nahīn kar saktā hūn. Mujhe market men jānā paregā. Market kiskā hai? Brāhmanvvādiyon kā hai. (I will find my way. Even if that system is Brahmanical, so by using that Brahmanical system I will raise the money. You will go for an academic career. If I go into academics, I cannot raise the money. I will have to go to the market. The market belongs to whom? It belongs to the followers of Brahmanical ideology.)

The more intense the discussion was getting, the more Devan became frustrated and started to lose control of his emotions. He was in front of two activists and also in front of a female researcher, unable to make his point in a convincing manner. Devan had a habit of spitting on the ground, and this worsened in moments of emotional excitement. Raju had an advantage because he had his activist friend near, had positioned himself as the questioner and appeared to be in better command of himself. After ten minutes of dispute, Raju told me to stop the recorder.

To interrupt the tense discussion, we went to Mamus dhāba for a tea. Devan was frustrated and was spouting the following arguments: that he is not the only one who thinks like this, that there is a contradiction in the movement, that he is socially frustrated, that he has a team, that he is planning to make a cultural revolution, and so 
on. Prem sarcastically reproached Devan by saying, "You have multiple personalities, have you visited a hospital?" In a similar vein, Raju approached him with "You need to go to Allahabad." Raju asked me if I understood what he meant by Allahabad. When I said no, he explained "You have been to Agra, no? There is a mental hospital there, so there is one in Allahabad." When Devan went to retrieve his bag, Raju and Prem started asking me what I was doing with this paggal (crazy) guy and how I came to choose "these kinds of people" for my research. Raju noted that I needed to choose people to communicate with "who have something to do with the movement."

\section{Symbolic Boundary in the Making}

As the vignette suggests, the moral demand of "paying back to society" promulgated by the Dalit movement is at the center of the student debate. This can be seen in the repetition of the Hindi verb dena (to give) in the previously cited dispute, which is a direct reference to this demand. Apparently, this moral ideal of "giving back to society" was ubiquitous among the students, but they related and interpreted it differently due to the experiential and class differences that separated them.

Raju, coming from an economically and educationally disadvantaged background, had developed a strong anti-Brahmanical and anti-Hindu attitude, and was proud of being involved in the Dalit "struggle." Devan, who belongs to an educated, Ambedkarite family background, got involved in friendships with upper-caste people and refrained from Dalit student activism, yet sympathized with the Dalit cause. The students' preuniversity background and economic position significantly affected the way caste was experienced by both of them during their formative years and in the ethnographic present on campus. As a politically active Dalit, Raju spoke in terms of collectivity and community. For him Dalit politics constituted one of the main avenues for social mobility. Meanwhile Devan, as a member of the middle class from birth had accumulated the kind of capital that allowed him to take an individualistic stance to the world at large and to venture into social experimentation.

One might wonder whether this conflict does not simply reflect the tensions arising from the different class positions of students. Undoubtedly, class differences play a role in the above conflict. However, I believe that the central point of disagreement focuses on the moral positioning and ideological alignment associated with the Dalit movement. From my experience, I believe that the encounter between students would have taken a very different turn if Devan, instead of pronouncing his alternative views, had expressed his loyalty to the movement. During my fieldwork, I met relatively affluent students of non-SC origin who were well integrated into the Dalit student circles due to their ideological alignment with the discourse of the Dalit movement proving social position is not the primary issue of contention.

While discussing the described conflict, we cannot talk about social mobility, morality and ideology as separate things, but rather should take into account their interrelatedness. Social mobility in India is largely understood in terms of collectivitycaste communities (Fuller and Narasimhan 2014; Naudet 2008, 2018; Osella and Osella 2000; Still 2011). Meanwhile, individual trajectories of social mobility are less explored (for a literature review see Vaid 2018). In the described situation we can see how collective and individual imaginaries of social mobility interact. The conflict among students erupted because while talking about his future plans Devan 
approached the moral obligation of "paying back to society" in a symbolically oppositional way to that of Raju and in so doing also questioned Raju's moral authority. Devan openly said that he is an opportunist and that he is ready for anything, even adopting Brahmanical ways to reach his goal of middle class standing and professional success. For the Dalit activists, this must have sounded like a selfish goal and a betrayal of the collective Dalit struggle. Social responsibility plays a central role in defining the meaning of Dalitness, which in a broadest sense means approaching the future asserting Dalit identity, supporting the Dalit movement and working for the Dalit cause. Upward social mobility, if not followed by the social and political commitment to the Dalit community, is not justified and is seen as immoral and deviant (Yengde 2019).

Robbins (2007) and Zigon(2009) discuss two types of moralities-"morality of reproduction" and "morality of freedom" (2007:296; 2009:252). This is a distinction between culturally constructed/reproduced morality and the morality which comes through the conscious freedom of choice. As a Dalit activist, Raju is in a way obliged to reproduce the discourse of the Dalit movement. He has to motivate others to be politically active and to join the Dalit movement. Meanwhile, Devan, as an artist and non-activist, has some freedom to question the imposed morality. Though apparently tacitly aligning with the moral demand of the movement, he does not want to be limited by Dalit politics nor their strictly constructed worldview. As a socioeconomically advanced student, Devan can choose and negotiate his moral views and, most probably, his existence does not depend anymore on the Dalit community. While for Raju, as a first generation educated person, the Dalit community's support is existentially important and, therefore, "paying back to society" becomes his guiding moral principle. We can surmise that for Raju "paying back to society" is a necessity, while for Devan it is a choice.

The moral views of Raju about his obligations to his primary social identity as a Dalit could be seen as shaped within one moral-value sphere, which is largely defined by the ideology of the Dalit movement. In this particular situation, his moral views appear to be consistent and unproblematic because as an activist he is representing Dalit cause. Devan, quite contrary, seems to be pulled between different moral-value spheres, between the social responsibility of the Dalit movement and the individualistic "opportunism" of the closed and highly competitive professional world of art. In the same interview, he explained to Raju "In that field where I am going there is no way for a person like me, all doors all closed...if you are talking about cinema, art. So you are not going to find a person like me, you are not going to find Ambedkarvadi." Interestingly, previously Devan distanced himself from Ambedkarites, meanwhile, in these lines we hear him placing himself among them. In the interview, as well as on other occasions, Devan repeatedly described himself as being "socially frustrated" and "seeing contradiction in the movement." This might be related to the fact that he was motivated by the ethic ideal of the Dalit movement, however, he has had to adapt his behavior to the real life situation, in which Ambedkarism does not always offer an easy solution. Such moments of dilemma, or "moral breakdowns," when ethical ideals are confronted by reality and the individual discover himself "caught in this betwixt state," offer the opportunity for a comprehensive anthropological exploration of morality (Zigon 2007:140). ${ }^{21}$

35 It is also interesting to observe to what extent Dalit moral ideology is internalized even by those who question it. Though Devan claims that he does not believe in 
Ambedkarites and even though he refrains from participating in Dalit student activism, in his actual actions he is not detached from the Dalit issues. Devan openly claims that he is working for the Dalit cause in his own "cultural" ways and is therefore aligning with the movement's "paying back to society" moral demand. (It must be noted that he may have considered that doing things under the "Dalit" banner is likely to bring some symbolic and social benefits). However, instead of expressing his absolute loyalty to the Dalit movement and its ideology, Devan voices independent views on political activism. This "independent thought" leads Dalit student activists to question his mental state. Devan's tacit moral alignment does not gain him recognition, consistent with that of the dominant Dalit moral type, from his peers. Paradoxically, both Devan and Raju construct their social mobility projects in relation to the Dalit movement, one through political activities, the other through cultural. They each consider their method as being the more moral. However, they appear unable to see their shared "moral ideals" because of initial pre-categorization and a mutual sense of competition.

In the described students' encounter we can see distancing, differentiation and hierarchy construction among the SC students. Devan distances himself from Dalit student activism and claims that he does not believe in Ambedkarites. Meanwhile, Raju assumes moral superiority over Devan, judging him to be a "not-paying-back" Dalit. He thus engages in the behavior typical in symbolic boundary-making by "impos[ing] a specific meaning as legitimate" (Lamont and Molnár 2002:172), i.e. by claiming that "paying back to society" has to be done through political means. Interestingly, throughout the students' interaction, we hear only Devan defending his views while Raju's views are taken for granted as legitimate, as if the movement's discourse need not be spoken out and justified. The assertion of moral superiority often goes hand in hand with boundary-making and the construction of some sort of inequality as Le Espiritu (2001) shows in his analysis of Filipino immigrants in the USA. ${ }^{22}$

37 A considerable amount of empirical research has already delved into the domination and inequality question within the SC community. Naudet (2008) has suggested that "upwardly mobile Dalits prefer to be dominant among the dominated than dominated among the dominant" and that among them "there is both a wish to become dominant economically and socially and a reluctance to become like those who are currently dominant" (p.435). Ciotti (2006) has demonstrated how unequal access to education fragments Dalit community and creates new inequalities. Ovichegan (2015) argues that there is "a growing divide between the creamy layer (usually urban) Dalit and the Quota Dalit (rural/urban and less privileged)" and that the quota scheme, instead of bringing only positive results, becomes a source of division within the Dalit community (pp.148-9). He observed that "creamy layer" Dalits "form privileged groups in which they are comfortable, and perpetuate their internalized biases against other, less privileged Dalit students;" that they are "individualistic and seem to prefer to separate themselves from other factions within their community" (p.149). These scholars agree on the point that the reservation policy and education can work to produce class inequality and domination among the SCs, enabling the formation of tangible social boundaries among Dalits.

In the student encounter described in this article we see another type of boundary in the making. This conflict was not about being a richer or poorer Dalit. It was about the reproduction of the Dalit movement's moral ideology and worldview and the meaning of Dalitness. What finally established a symbolic boundary between the students was 
Devan's political disengagement and his mention of "opportunism" and "Brahmanical ways," which are anathema to Dalit activists for going against the moral ideal of the Dalit social mobility.

Naudet has argued that "paying back to society" serves as a stabilizing narrative that neutralizes tensions arising from upward social mobility (Naudet 2018). In this article I have demonstrated that "paying back to society" for some SC students provides an empowering ideological program for social upliftment, while for others it is an ideological imposition limiting free human agency. This case study shows that among the SC students tensions appear not from the upward social mobility alone but also from the ideological framing of morality. Moral demands, such as "paying back to society," may result in stability and continuity, as Naudet has argued. However, they can also, sometimes, become a point of disagreement and contestation and an impetus of new symbolic boundaries.

\section{Conclusion}

Despite "paying back to society" being a significant moral demand of the Dalit movement, there is an apparent complexity of moral views and multiple social mobility imaginaries evoking tensions among SC students. Dalit moral order, centered on "paying back to society," is a political project that is debated and differently defined, protected by some and threatened by others. Also a center of moral gravity, it is defining symbolic boundaries within the Dalit community. These boundaries are porous and implicit, but nevertheless real in establishing if not hard divisions, at least separateness of interest and goals. While discussing the student encounter, it was inevitable to address "paying back to society" as a "totalizing moral discourse" (Zigon 2014a:18) and to recognize its structuring effect. Of this pervasive normative ideological claim, none of the students, no matter their background or economic status, appears completely free. However, we could see how students disagreed over which means of "paying back to society" is more moral and legitimate; through this disagreement the plurality of moralities becomes apparent.

41 I began this article by discussing how the Dalit movement has been reproducing social and moral categorizations and then, through ethnographic vignette, I presented how this categorization played out in an actual social situation among students. One can consider social and moral categorization among Dalits as being descriptive, mirroring existing socio-economic differences in society. However, categorization can be also understood as being prescriptive, reifying the not yet firmly established differences and boundaries and predetermining how individuals will perceive and relate to each other. In this case, the discussed students' interaction was largely shaped by the prescriptive categorization, which has been instrumentally maintained by the Dalit movement. Raju and Devan reproduced and applied to each other existing categoriescommunity oriented Dalit activist vs. opportunist middle class Dalit-without realizing that their moral views, at the core, were not that incompatible. They both support and follow the Dalit code of moral conduct, "paying back to society," in disagreement simply over the nature and the form of giving. This interaction demonstrates how predetermined categorizations either of each other as individuals or of those established as "Dalitist" do not account for the multiple moralities and differing ideological alignments within the group as a whole. 


\section{BIBLIOGRAPHY}

Altbach, Philip G. 1968. “Student Politics and Higher Education in India.” Daedalus 97(1):254-73.

Batabyal, Rakesh. 2015. JNU: The Making of a University. New Delhi: Harper Collins.

Blom, Amélie and Nicolas Jaoul. 2008. "Introduction; The Moral and Affectual Dimension of Collective Action in South Asia." South Asia Multidisciplinary Academic Journal 2. Retrieved on January 9, 2020 (https://journals.openedition.org/samaj/1912?lang=fr).

Bornstein, Erica. 2012. Disquieting Gifts: Humanitarianism in New Delhi. Stanford: Stanford University Press.

Burawoy, Michael. 1998. "The Extended Case Method." Sociological Theory 16(1):4-33.

Charsley, Simon. 1998. "Sanskritisation: The Career of an Anthropological Theory." Contributions to Indian Sociology 32(2):527-49.

Charsley, Simon. 1996. “'Untouchable': What is in a Name?" The Journal of the Royal Anthropological Institute 2(1):1-23.

Ciotti, Manuela. 2006. "In the Past We Were a Bit "Chamar"': Education as a Self- and Community Engineering Process in Northern India." The Journal of the Royal Anthropological Institute 12(4):899916.

Copeman, Jacob. 2011. "The Gift and Its Forms of Life in Contemporary India." Modern Asian Studies 45(5):1051-94.

Corbridge, Stuart and John Harris. 2000. Reinventing India: Liberalization, Hindu Nationalism and Popular Democracy. Cambridge: Polity Press.

Das, Veena. 2012. “Ordinary Ethics." Pp. 133-49 in A Companion to Moral Anthropology, edited by D. Fassin. Malden, MA: Wiley-Blackwell.

Desai, Sonalde and Veena Kulkarni. 2008. "Changing Educational Inequalities in India in the Context of Affirmative Action.” Demography 45(2):245-70.

Fuller, Christopher John and Haripriya Narasimhan. 2014. Tamil Brahmans: The Making of a Middleclass Caste. Chicago: The University of Chicago Press.

Garalytè, Kristina. 2016. "Dalit Student Movement in India: From Identity Politics to Counter Culture Movement." PhD dissertation, Department of Social Sciences, Vytautas Magnus University.

Garalytė, Kristina. 2015. “Subaltern Autonomy: Dalit Students' Identity Politics in India.” Grupes ir aplinkos 4:49-76.

Gundimeda, Sambaiah. 2009. "Democratization of the Public Sphere: The Beef Stall Case in Hyderabad's Sukoon Festival." South Asia Research 29(2):127-49.

Guru, Gopal. 1998. “The Politics of Naming.” Seminar. Retrieved on November 18, 2019 (http:// www.india-seminar.com/2018/710/710_gopal_guru.htm)

Guru, Guru and Sundar Sarukkai. 2013. The Cracked Mirror. An Indian Debate on Experience and Theory. New Delhi: Oxford University Press.

Hirslund, Dan Vesalainen. 2012. "Sacrificing Youth: Maoist Cadres and Political Activism in PostWar Nepal." PhD dissertation, Department of Social Sciences, University of Copenhagen. 
Ilaiah, Kancha. 2009. Why I am not a Hindu: A Shudra Critique of Hindutva Philosophy, Culture and Political Economy. Calcutta: Samya.

Jaffrelot, Christophe. 2003. India's Silent Revolution: The Rise of the Lower Castes in North India. London: Hurst \& Company.

Jaoul, Nicolas. 2008. “The 'Righteous Anger' of the Powerless. Investigating Dalit Outrage over Caste Violence." South Asia Multidisciplinary Academic Journal (SAMAJ). Retrieved on December 12, 2019 (https://journals.openedition.org/samaj/1892).

Jeffrey, Craig. 2010. Timepass: Youth, Class, and the Politics of Waiting in India. Stanford: Stanford University Press.

Jeffrey, Craig. 2008. "Kicking Away the Ladder: Student Politics and the Making of an Indian Middle Class." Environment and Planning D: Society and Space 26:517-36.

Jeffrey, Craig and Jane Dyson. 2014. “'I serve therefore I am': Youth and Generative Politics in India." Comparative Studies in Society and History 56(4): 967-994.

Kumar, Satendra. 2012. "Ethnography of Youth Politics: Leaders, Brokers and Morality in a Provincial University in Western Uttar Pradesh." History and Sociology of South Asia 6(1):41-70.

Lambek, Michael. 2010. "Introduction” Pp. 1-36 in Ordinary Ethics: Anthropology, Language, and Action, edited by M. Lambek. New York: Fordham University Press.

Lamont, Michèle and Marcel Fournier. 1992. "Introduction." Pp. 1-17 in Cultivating Differences: Symbolic Boundaries and the Making of Inequality, edited by M. Lamont and M. Fournier. Chicago and London: The University of Chicago Press.

Lamont, Michèle, Sabrina Pendergrass, and Mark C. Pachucki. 2015. "Symbolic Boundaries." Pp. 850-855 in International Encyclopedia of Social and Behavioral Sciences, edited by J. Wright. Oxford: Elsevier.

Lamont, Michèle and Virág Molnár. 2002. "The Study of Boundaries in the Social Sciences." Annual Review of Sociology 28:167-95.

Le Espiritu, Yen. 2001. “'We Don't Sleep around like White Girls Do': Family, Culture, and Gender in Filipina American Lives.” Signs 26(2):415-40.

Martelli, Jean-Thomas. 2020. "The Spillovers of Competition: Value-Based Activism and Political Cross-fertilization in an Indian Campus." South Asia Multidisciplinary Academic Journal 22.

Martelli, Jean-Thomas and Khaliq Parkar. 2018. "Diversity, Democracy, and Dissent: A Study on Student Politics in JNU." Economic and Political Weekly 53(11). Retrieved on November 18, 2019 (https://www.epw.in/engage/article/diversity-democracy-dissent-study-student-politics-JNU) Naudet, Jules. 2018. Stepping into the Elite: Trajectories of Social Achievement in India, France, and the United States. New Delhi: Oxford University Press.

Naudet, Jules. 2008. “'Paying Back to Society': Upward Social Mobility Among Dalits.” Contributions to Indian Sociology 42(3):413-41.

Oinas, Elina, Henri Onodera, and Leena Suurpää. 2018. "Evasive Youth, Oblique Politics." Pp. 1-20 in What Politics? Youth and Political Engagement in Africa, edited by E. Oinas, H. Onodera, and L. Suurpää. Leiden; Boston: Brill.

Osella, Filippo and Caroline Osella. 2000. Social Mobility in Kerala: Modernity and Identity in Conflict. London: Pluto. 
Ovichegan, Samson K. 2015. Faces of Discrimination in Higher Education in India: Quota Policy, Social Justice and the Dalits. London, New York: Routledge.

Ovichegan, Samson K. 2014. "Social Exclusion, Social Inclusion and 'Passing': The Experiences of Dalit Students at One Elite Indian University." International Journal of Inclusive Education 18(4):35978.

Pandian, Anand and Daud Ali, eds. 2010. Ethical Life in South Asia. Bloomington, IN: Indiana University Press.

Pandey, Priyanka and Sandeep Pandey. 2018. "Survey at an IIT Campus Shows How Caste Affects Students' Perceptions." Economic and Political Weekly 53(9). Retrieved on November 18, 2019 (https://www.epw.in/engage/article/Survey-at-an-IIT-Campus-Shows-How-Caste-AffectsStudents-Perceptions)

Pathania, Gurav J. 2018. University as a Site of Resistance: Identity and Student Politics. New Delhi: Oxford University Press.

Pathania, Gurav J. 2016. "Food Politics and Counter-hegemonic Assertion in Indian University Campuses." South Asia Research 36(2):261-77.

Pathania, Gaurav J. and William G. Tierney. 2018. "An Ethnography of Caste and Class at an Indian University: Creating Capital.” Tertiary Education and Management 24(3):221-31.

Ram, Kanshi. 1982. The Chamcha Age: An Era of the Stooges. New Delhi: Vedic Mudranalaya.

Robbins, Joel. 2007. "Between Reproduction and Freedom: Morality, Value, and Radical Cultural Change." Ethnos 72(3):293-314.

Robbins, Joel. 2004. Becoming Sinners: Christianity and Moral Torment in a Papua New Guinea Society. Berkley, Los Angeles, London: University of California Press.

Sen, Sahana and Nagaraju Gundemeda. 2015. "The Idea of a University: A Sociological Study of a National University in India." Journal of Sociology and Social Anthropology 6(1):99-112.

Shah, Ghanshyam. 2004. Social Movements in India: A Review of Literature. New Delhi: Sage.

Snellinger, Amanda Thérèse. 2018. Making New Nepal: From Student Activism to Mainstream Politics. Seattle: University of Washington Press.

Srinivas, Gurram. 2016. Dalit Middle Class: Mobility, Identity and Politics of Caste. New Delhi: Rawat Publications.

Srivatsan, R. 2019. Seva, Saviour and State: Caste Politics, Tribal Welfare and Capitalist Development. London: Routledge.

Still, Clarinda. 2011. "Spoiled Brides and the Fear of Education: Honour and Social Mobility among Dalits in South India.” Modern Asian Studies 45(5):1119-46.

Teltumbde, Anand. 2008. Khairlanji. A Strange and Bitter Crop. New Delhi: Navayana.

Webster, John C. B. 2007. “Who is a Dalit?” Pp. 76-91 in Dalits in Modern India, edited by S. M. Michael. New Delhi: Sage Publications.

Wilkinson, Tom. 2020. "Student Politics in British India and Beyond: The Rise and Fragmentation of the All India Student Federation (AISF), 1936-1950." South Asia Multipliscinary Academic Journal. Vol. 22.

Yengde, Suraj. 2019. Caste Matters. Gurgaon: Penguin. 
Vaid, Divya. 2018. Uneven Odds: Social Mobility in Contemporary India. New Delhi: Oxford University Press.

Zigon, Jarrett and C. Jason Throop. 2014. “Moral Experience: Introduction.” Ethos 42(1):1-15.

Zigon, Jarrett. 2014a. "Attunement and Fidelity: Two Ontological Conditions for Morally Being-inthe-World." Ethos 42(1):16-30.

Zigon, Jarrett. 2014b. "An Ethics of Dwelling and a Politics of World-building: A Critical Response to Ordinary Ethics." Journal of the Royal Anthropological Institute 20:746-64.

Zigon, Jarrett. 2009. “Within a Range of Possibilities: Morality and Ethics in Social Life." Ethnos $74(2): 251-76$.

Zigon, Jarrett. 2007. "Moral Breakdown and the Ethical Demand: A Theoretical Framework for an Anthropology of Moralities.” Anthropological Theory 7(2):131-50.

\section{NOTES}

1. Naming of untouchables has been a controversial question (Charsley 1996; Guru 1998; Webster 2007) and none of the existing labels avoid certain pitfalls. Firstly, since the Constitution of India outlawed the practice of untouchability in 1950, there is a consensus to denote these culturally and experientially diverse people using the prefix "ex-" or "former-" before "untouchables." However, in certain contexts untouchability is still practiced in its cruelest forms, i.e. caste atrocities, which do not allow thinking of it merely in terms of the past (Jaoul 2008; Teltumbde 2008). Secondly, since the time of B. R. Ambedkar, the term Dalit has become the umbrella category with which to identify various groups that are known to belong to any of the untouchable caste groups, and is now considered the politically correct term for untouchables. However, the term Dalit is related to a certain political orientation involving anti-Hindu consciousness, which is not naturally accepted by all ex-untouchables. Additionally, it is not absolutely clear who can be named as a Dalit; opinions range from including only those marked by the experience of untouchability to including various types of groups affected by social stigmatization and subalternity (the latter tendency was promulgated by the Dalit Panther movement as well as the Bahujan Samaj Party more recently). Though the term Dalit was seen as carrying liberating potential, it cannot escape from turning into a hegemonic category imposing a certain type of political consciousness. Finally, Indian governmental categorization of various untouchable groups as the Scheduled Castes puts culturally diverse ex-untouchable sub-castes (jāti) into one artificial administrative mold. However, in some contexts such as Indian universities, the governmental categorization seems to have the most importance in people's lives compared to other terms. I endorse the view that one should be conscious and cautious when using one or another category denoting ex-untouchables and their particular usage context. In this article, I employ the term Dalit to indicate people who are the followers of Ambedkarite ideology; Scheduled Castes will be used as a generic term to name those who are of untouchable origin but who do not necessarily adhere to the Ambedkarite ideology and the Dalit movement.

2. My biggest thanks go to the protagonists of this article for allowing me stepping into their lives and for sharing their experiences. I am also grateful to Victor de Munck, Emilija Zabiliūte, Rūta Žukaitytè, Armin Chiocchetti and the anonymous reviewers for their insightful comments and suggestions.

3. In the Nepali context, student and youth activism has been conceptualized as social service (Snellinger 2018) and sacrifice (Hirslund 2012). 
4. Drawing on Weber, Robbins suggested to view society as constituted of distinct and incompatible moral-value spheres. "Morality of reproduction" happens within one moral value sphere, meanwhile, "morality of freedom" comes to the fore when a person discovers herself stuck between two conflicting moral value spheres and has to figure out her moral positioning (Robbins 2007:298-300; Zigon 2009:252-53).

5. Raju's case will reconfirm Naudet's argument about tension-less social mobility, while Devan's case will contradict it.

6. Changes included the expansion of the reservation policy to Other Backward Classes, economic liberalization, the rise of the Hindu Right and leading communal conflicts, and the emergence and success of the Dalit political parties (Corbridge and Harriss 2000; Jaffrelot 2003).

7. The idea of Dalit counter-culture emerged on Hyderabad university campuses (The University of Hyderabad, Osmania University, The English and Foreign Languages University) from around 2010 onwards. Dalits began claiming that they were the ancestors of mythic Asuras (dark and fierce demons in Hindu mythology) or historical Dravidians (local inhabitants of the Indian subcontinent conquered by the invader Aryans), and staged performative commemorations of death anniversaries of various Asura characters that were cruelly killed by Hindu gods or upper caste Aryans. These commemorations served as an assertion of Dalit identity and, most importantly, as a reference to various caste atrocities against Dalits. Dalit students have also been staging performative beef eating festivals on Hyderabad university campuses, thus trying to destigmatize beef as a food item questioning the hegemony of Hindu vegetarianism, and simultaneously attempting to give a positive sense to their own identity. Though initially started as an assertion of the Dalit culture and identity, these festivals have developed into the broader anti-establishment, counter-culture initiative, uniting different student groups that were against the Hindu Right politics and the caste system.

8. Though in this article I present material only form JNU, I rely on a continuous multi-sited fieldwork and online observation of the Dalit student activism in New Delhi and Hyderabad university campuses (The Jawaharlal Nehru University, The University of Delhi, The English and Foreign Languages University, Osmania University, The University of Hyderabad) since 2013.

9. Term Bahujan (majority) was popularized by the BSP (Bahujan Samaj Party) - Dalit party that was founded by Kanshi Ram in the Uttar Pradesh state in 1984. The term has been used to represent Scheduled Castes, Scheduled Tribes, Other Backward Classes and religious minorities.

10. Author's interview with Prem at JNU, May 23rd, 2013.

11. This trend was interrupted by the emergence of BAPSA (Birsa Ambedkar Phule Student Association) in 2014 which relatively successfully contested the JNUSU elections in 2016.

12. These claims found their expression in the Beef and Asura counter-culture celebrations that have been rocking some of the university campuses in Hyderabad, and to a lesser extent JNU, since around 2010.

13. I have codded the names of the informants and also changed the minor biographical details in the narrative to mask their identities.

14. One of the traditional practices of untouchability is related to preventing untouchables from fetching and drinking water from the common water sources. Among Dalits, water has gained a deep symbolic meaning, not only as a source of discrimination, but also as a means of resistance. In 1927 B. R. Ambedkar initiated Mahā he and his followers fetched water from the public water tank in Mahad locality. When telling their life stories, Dalit students quite often refer to "water incidents" that have happened in their lives, thus aligning their personal experiences with the grand narrative of the Dalit movement.

15. Prem appears episodically in the narrative as he did not take a central role in the discussed conflict.

16. Jotiba Phule (1827-1890) was an anti-caste social activist and writer from the Maharashtra state, belonging to the Mali (gardener) caste that today would be categorised as the $\mathrm{OBC}$. $\mathrm{He}$ 
promoted the idea of the unity between Shudras (present-day OBCs) and ati-Shudras (presentday SCs) and worked to educate them. Phule has become an ideological icon not only among OBCs but also among SCs and gained a respectable place in the Dalit ideological pantheon.

17. Agräharam is an area of a village in Tamil Nadu where Brahmins reside.

18. In 2013, The University of Delhi implemented Four Year Undergraduate Program (FYUP) reform, which extended undergraduate studies from three to four years. Among other arguments, this reform was seen as creating hardships for SC, ST and OBC students, by increasing educational load and financial costs. There was a series of protests against the reform in 2013 and 2014. Various student organizations from JNU jointly supported the FYUP protests.

19. Author's interview at JNU with Prem, Raju and Devan, May $23^{\text {rd }}, 2013$.

20. Youth in the global South often equates formal politics with corruption and "gerontocratic power structures" (Oinas, Onodera and Suurpää 2018:12), meanwhile attributing a positive meaning to the youth political engagement as "generative politics" (Jeffrey and Dyson 2014).

21. The reader might sense a certain imbalance or even injustice in my description of the two students' moral views, as I depict Devan in terms of moral complexity and Raju in terms of moral uniformity. Looking from Zigon's (2007) perspective, only Devan's case could be interpreted as a truly "ethical moment," (p.148) revealing his moral dilemmas and confusion in defining his own identity and negotiating his way of "paying back to society." I am aware that there is a much greater complexity in Raju's moral positioning than what I could access and what got revealed in the described situation. Also, it is worth keeping in mind that Raju's identity and position as a Dalit student activist might have significantly affected not only his moral positionality, but also his freedom to express himself. Furthermore, from the point of view of research ethics, I have more freedom to reveal personal details about Devan, because he was not a public figure on campus and, therefore, he is not easily identifiable, quite contrary to Raju.

22. The role of moral demands in symbolic boundary making has been analyzed by Le Espiritu (2001) in the context of Filipinos immigrants in the USA. He has shown how Filipina Americans asserted moral superiority over "white" Americans by criticizing the morality of white women and at simultaneously restricting their own women's freedom (2001).

\section{ABSTRACTS}

Emerging literature on Dalit student activism explores the ways Dalit students position themselves with regard to other student groups and the broader caste structure. However, less attention has been paid to intragroup relations and dynamics within the community of Scheduled Caste (SC) students. This article explores the emerging differentiation and boundarymaking among the SC students, thus contributing to the ongoing discussion on differences and divisions within the larger Dalit community. Focusing on symbolic boundaries, morality and socio-political backgrounds, I discuss the actual conflict between two SC students, in which they debated the moral dictate of the Dalit movement of "paying back to society." Though both students seem to have internalized the moral demand, their perspectives on how to implement it differed. One student I shall call Raju advocated that paying back should be done through political action; the other student, Devan, argued that artistic expression is an equally legitimate way to "pay back to society." The two protagonists also had substantively different relations with regard to the Dalit student organizations that advocated for political activism and "paying back to society." For Raju, Dalit political activism served as a main avenue for personal upward social 
mobility, while Devan viewed political activism as a restrictive imposition limiting other legitimate means for "paying back to society." I argue that symbolic boundaries between students cannot be reduced to class or caste distinctions, but rather that they are based on differing ideological and moral alignments. While acknowledging the influence of Ambedkarite ideology in forming students' moral views, this case study shows that SC students do not espouse a single ideology or moral stance regarding modes of political activism, which brings out tensions that arise at the intersection between Dalit movement's ethics and multiple individual moralities. The paper also describes two different ways students may imagine their social mobility.

INDEX

Keywords: Dalits, student activism, symbolic boundaries, moral demands

\section{AUTHOR}

\section{KRISTINA GARALYTÉ}

Assistant Professor, Institute of Asian and Transcultural Studies at Vilnius University 